\title{
Winter Thermal Ecology Of Pleurodema thaul (Amphibia: Leptodactylidae)
}

\section{Ecología térmica en Invierno de Pleurodema thaul (Amphibia: Leptodactylidae)}

\author{
Myriam IturRa-Cid ${ }^{1}$ * Marcela Vidal ${ }^{2}$, Antonieta Labra ${ }^{3}$ \& Juan Carlos Ortiz ${ }^{1}$ \\ ${ }^{1}$ Laboratorio de Herpetología, Departamento de Zoología, Universidad de Concepción, Casilla 160-C, Concepción, Chile \\ 2Departamento de Ciencias Básicas, Facultad de Ciencias, Universidad del Bío-Bío. Casilla 447, Chillán, Chile \\ ${ }^{3}$ Centre for Ecological and Evolutionary Synthesis, Department of Biology, University of Oslo, PO Box 1066 Blindern, N-0316 \\ Oslo, Norway \\ Email: myiturra@udec.cl
}

\begin{abstract}
The biodiversity of the entire planet is threatened by global warming, and among vertebrates, Amphibia is the taxon most negatively affected by this problem. Amphibians depend on an external heat source to achieve and maintain an adequate body temperature, which has a significant impact on their fitness. Therefore, an increase in the average environmental temperature will affect, probably in a negative way, the general performance of amphibians. This makes it imperative to increase our scarce knowledge of amphibian thermoregulation. The aim of this work is to contribute to the knowledge of amphibian thermoregulation by studying the winter thermal ecology of one of the most widely distributed species in Chile, Pleurodema thaul. Individuals were collected during the mid-austral winter in Península de Hualpén, which corresponds to the midpoint of the latitudinal range of distribution of $P$. thaul. In the field and laboratory we recorded body temperature and the substrate and air temperatures. The data indicate that $P$. thaul is a thermoconformer, as its body temperature varies during the day, following the temperature of the substrate and the air. Pleurodema thaul does not seem to use morphological body properties to facilitate thermoregulation; body temperature was unrelated to the body size or weight of individuals. The fact that during winter $P$. thaul does not thermoregulate actively constitutes a clear indication that the global warming may have serious effects on this species.
\end{abstract}

KEYWORDS: Anuran, thermobiology, thermoconformism.

\section{RESUMEN}

La biodiversidad de todo el planeta se encuentra amenazada debido a los efectos del calentamiento global, y dentro de los vertebrados, los anfibios son los más afectados por este problema. Los anfibios dependen de fuentes externas de calor para alcanzar y mantener una adecuada temperatura corporal, lo cual tiene un impacto significativo en su adecuación biológica. Por lo tanto, un aumento en la temperatura media del ambiente afectará, probablemente en forma negativa, el desempeño general de los anfibios. Esto hace que sea imperativo incrementar nuestro escaso conocimiento respecto a la termorregulación de anfibios. El objetivo de este trabajo es contribuir al conocimiento de la termorregulación de estos organismos mediante el estudio de la ecología térmica en invierno de una de las especies de más amplia distribución en Chile, Pleurodema thaul. Los individuos fueron recolectados en invierno en la Península de Hualpén, que corresponde al punto medio del rango latitudinal de distribución de $P$. thaul. En terreno y en laboratorio se registró la temperatura corporal y las temperaturas de sustrato y el aire. Los datos indican que $P$. thaul es una especie termoconforme, ya que su temperatura corporal varía durante el día según varía la temperatura del substrato y del aire. Pleurodema thaul no parece utilizar las propiedades morfológicas del cuerpo para facilitar la termorregulación, ya que la temperatura del cuerpo no se relaciona con el tamaño corporal o el peso de los individuos. El hecho de que durante el invierno $P$. thaul no termorregule activamente constituye un claro antecedentes que el calentamiento global puede ocasionar graves efectos sobre esta especie.

Palabras Claves: Anura, termobiología, termoconformismo. 


\section{INTRODUCTION}

Global warming, the increase in the average temperature of the earth, is imposing severe changes in the biology of most living species (Parmesan et al. 1999; Laurance 2008; Feehan et al.2009). This problem is more serious for ectotherms such as amphibians due to their lack of thermogenesis, thus their high dependence on an external source of heat to achieve and maintain an adequate body temperature (Jorgensen 1992). These constraints for thermoregulation make body temperature an extremely important variable that modulates the physiology, ecology and evolution of this taxon (Cossins \& Bowler 1987; Anguiletta et al. 2002; Castañeda et al. 2004, Sinervo et al. 2010). Therefore, amphibian thermal ecology is fundamental to their evolutionary and ecological success (Gilchrist 1995; Pörtner 2002).

For amphibians, however, temperature is not the only factor which modulates their biology; moisture is the other important determinant (Sanabria et al. 2014). In fact, the effectiveness of basking behaviour is severely constrained in most anurans due to their limited ability to control evaporative water loss (Carey 1978; Navas et al. 2002). Therefore, in contrast to lizards, amphibians are rarely observed in sunny patches (e.g. Pearson \& Bradford 1976; Labra et al.2008), and these restrictions for thermoregulation make most amphibians thermoconformists, i.e. their body temperature strongly correlates with the air and/or substrate temperature (Lambrinos \& Kleier 2003). Recently it was claimed that one important way in which ectotherms can reduce the effect of climate change is by behavioural thermoregulation (e.g. Kearney et al. 2009). However, due to the limitations that amphibians have for behavioural thermoregulation they are much more threatened, compared to lizards for example, by the increase of global temperature, as in fact has been shown by different studies (Alford \& Richards 1999; Gibbons et al. 2000; Alford et al. 2007).

Felton et al. (2009) indicated that regions such as Latin America, rich in biodiversity, probably with low adaptive capacity to climate change, are not well studied from a conservation point of view, and that taxa such as amphibians have received very little attention. In fact, in Chile, the situation is very critical. This country has a relative richness of amphibian fauna (63 species, Lobos et al 2013), but the knowledge about basic aspects of their biology, including thermoregulation, is close to null (Vidal \& Labra 2008)

Our aim is to reduce the lack of information on amphibian thermal ecology, starting by studying one of the most widely distributed and most abundant Chilean frogs, Pleurodema thaul, the "four-eyed frog". In Chile, this species is distributed from Copiapó $\left(27^{\circ} 22^{\prime} \mathrm{S}, 70^{\circ} 20^{\prime} \mathrm{W}\right)$ to Aysén $\left(45^{\circ} 30^{\prime} \mathrm{S}, 70^{\circ} 20^{\prime} \mathrm{W}\right)$ and from the coast to $2700 \mathrm{~m}$ above sea level (Correa et al. 2007). In a combined field and laboratory study, we explored the thermoregulatory capabilities of $P$. thaul: is this a thermoconformist or thermoregulator species? We also explored the possibility that morphology can contribute to $P$. thaul thermoregulation (see Labra \& Vidal 2003). We investigated whether body size is related to body temperature, considering that larger individuals, due to a smaller surface-volume relationship, should retain a given body temperature longer, decreasing their dependence on heat sources (Lillywhite et al. 1973). If our results suggest that $P$. thaul is thermoconformist, then this species is threatened by global warming.

\section{MATERIALS AND METHODS}

Field work was carried out in the Península de Hualpén, a Wildlife Sanctuary $\left(36^{\circ} 45^{\prime} \mathrm{S} ; 7^{\circ} 13^{\prime} \mathrm{W}\right)$. This is a transition area between the mesomorphic and hygromorphic phytogeographical regions (Quintanilla 1982), characterized by a wet (rainy) season of seven to eight months followed by a dry season. During the wet season rainfall may reach $1300 \mathrm{~mm}$; mean annual temperature is $12.2^{\circ} \mathrm{C}$ (7.1 to $18.4^{\circ}$ $\mathrm{C}$, minimum and maximum monthly means, respectively) (DEFAO, Universidad de Concepción).

Pleurodema thaul hibernates from May to July in this region; we collected 25 adults of $P$. thaul (11 females and 14 males) just after the hibernation period, between July and August. Immediately after capturing an individual we measured its body temperature $(\mathrm{Tb})$ and body mass $( \pm 0.01 \mathrm{~g})$. For this, individuals were held by one hind leg to avoid heat transfer, and a thermocouple was inserted in the vent. The procedure did not last more than one min, to prevent any potential change in temperature. The substrate temperature (Ts) was then recorded, i.e. the thermocouple was placed in contact with the substrate where the animal was found. In addition, Air temperature was measured to five $\mathrm{cm}$ above the substrate (Ta). Thermal records were made with a HI93532R thermometer $\left( \pm 0.01^{\circ} \mathrm{C}\right)$; thermocouples were type K. Frogs were transported to the Laboratory of Herpetology of University of Concepción; their body mass was recorded with a Belltronic ES-300 HA balance $( \pm 0.01 \mathrm{~g})$ and snout-vent length (SVL) was measured with a Mitutoyo calliper $( \pm 0.01 \mathrm{~mm})$. In addition, they were sexed by recognition of secondary sexual characters such as the vocal sac and/or nuptial excrescences on the first finger of the forehand (Penna \& Solís 1992; Díaz-Páez \& Ortiz 1995).

Frogs were housed in a room kept at $17 \pm 2.23{ }^{\circ} \mathrm{C}$ with a photoperiod of 11:13, L:D. They were maintained individually in terrariums $(10 \times 15 \times 10 \mathrm{~cm})$, with a substrate of grass, soil, and stones obtained in the collecting area. During the entire experimental period animals were fed twice 
a week with mealworms. They remained undisturbed for one week, allowing acclimatation to the experimental conditions. Thereafter, temperatures ( $\mathrm{Tb}$, Ts and Ta) were recorded twice a day, during the morning (between 8:30 and 10:30 A.M.) and in the afternoon (between 19:30 and 21:30 P.M.), which corresponds to the normal daily period of inactivity and activity in the field, respectively (Iturra-Cid, unpubl. data). To avoid pseudoreplication, the mean value of the different temperatures for the inactive and active period was obtained for each individual. The thermoregulatory capacities of $P$. thaul were evaluated using linear regressions of Ts, Ta, SVL and mass on $\mathrm{Tb}$ in lab. A t-test was used to compare $\mathrm{Tb}$ between sexes and body temperature in active and inactive hours (Sokal \& Rohlf 1995). Analyses were done with Statistica (StatSoft Inc. 2000). Data are shown as mean \pm SD. Prior to statistical analyses, all data were examined for assumptions of normality and homogeneity of variance, using Kolmogorov-Smirnov and Levene tests, respectively.

\section{RESULTS}

The mean body temperature of females was $12.07 \pm 0.8^{\circ} \mathrm{C}$ $\left(\right.$ range $=10.5-13.6^{\circ} \mathrm{C}$ ) and for males was $12.02 \pm 0.73^{\circ} \mathrm{C}$ $\left(\right.$ range $\left.=10.5-12.9^{\circ} \mathrm{C}\right)$. Because sexes had similar $\mathrm{Tb}\left(t_{23}=\right.$ $-0.14, P=0.74)$, data were pooled. Field $\mathrm{Tb}$ was positively correlated with Ts $(\mathrm{r}=0.77, \mathrm{P}=0.0001)$ and $\mathrm{Ta}(\mathrm{r}=0.74, \mathrm{P}$ $=0.0001$ ) (Fig. 1). In the laboratory, the body temperature of $P$. thaul was higher during the active than inactive hours $\left(19.5^{\circ} \mathrm{C} \pm 0.26,16.9^{\circ} \mathrm{C} \pm 0.28\right)\left(t_{50}=33.9, P<0.001\right)$, and showed a close relation with the pattern of the substrate and air temperature. In this ambient, $\mathrm{Tb}$ was positively correlated with Ta and Ts in activity (Fig. 2A) and inactivity (Fig. 2B). Also, we did not found any association between $\mathrm{Tb}$ and body $\operatorname{mass}(\mathrm{r}=0.1, \mathrm{P}=0.6)$ or size $(\mathrm{r}=0.02, \mathrm{P}=0.7)$ (See Fig. 3A and 3B).

\section{DISCUSSION}

Sometimes during field trips it was possible to hear individuals singing, indicating that animals were active. In inactivity periods the individuals were under stones and logs. In the laboratory, during the inactive period frogs were always found in burrows, and both during the active and inactive hours. However, it is interesting to note that during the inactive period, $\mathrm{Tb}$ showed a much closer relation with Ts and Ta than during the active period. In fact, during the night individuals were usually found active, out of their burrows. The significant correlations between the body temperature and environment temperatures (substrate and air) in the field and laboratory are clear indications that $P$. thaul is a thermoconformist, as has been shown for other anurans (Sanabria et al. 2005, 2006; Woolrich-Piña et al. 2006). On the other hand, $P$. thaul showed a higher thermal dependence on the substrate than on the air temperature, suggesting a tigmothermal regulation, consistent with the pattern observed in others species of amphibians (Sanabria et al. 2003).

Zug et al. (2001) proposed that individuals of small body size or in early stages of their development should have a higher body temperature than larger individuals (Keen \& Schroeder 1975; Casterlin \& Reynolds 1978), because small individuals exchange heat with the atmosphere much faster than larger individuals, which implies an increase in dehydration with a consequent increase in body temperature (Zug et al. 2001; Sanabria et al. 2003, Sinervo et al. 2010). However, we did not found any association between $\mathrm{Tb}$ and body mass or size, which suggests that $P$. thaul cannot use its body characteristics as a mechanism for thermoregulation (Labra et al. 2008), probably because of its small body size. In the laboratory, the body temperature of $P$. thaul was higher during the active than inactive hours, and showed a close relation with the pattern of the substrate and air temperature, as in other species (Lambrinos \& Kleier 2003). Our study was performed during mid-winter; a condition that favours thermoconformism due to the lower availability of thermal resources (Huey 1982; Labra et al. 2008). This thermoconformism may allow animals to save time and energy for other behaviours (Labra \& Vidal 2003, Sanabria et al. 2014), such as storing energy for reproduction. We cannot rule out, however, the possibility that during the summer $P$. thaul is a more active thermoregulator. Nevertheless, the high dependence that $P$. thaul has on the thermal environment can impose a serious problem for this species, at least during the winter period, such as changes in breeding time (e.g., Kusano \& Inoue 2008).

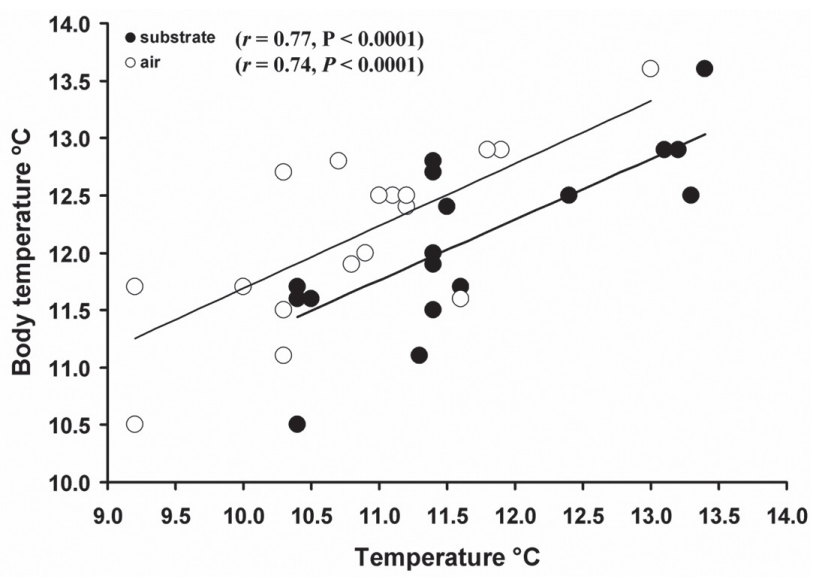

FIGURE 1: The relationship between body temperature and air and substrate temperature in field conditions. The correlation coefficient with its significance is given.

Figura 1: Relación entre la temperatura del cuerpo con la temperatura del aire y del sustrato en condiciones de terreno. Se entrega el coeficiente de correlación con su significancia. 

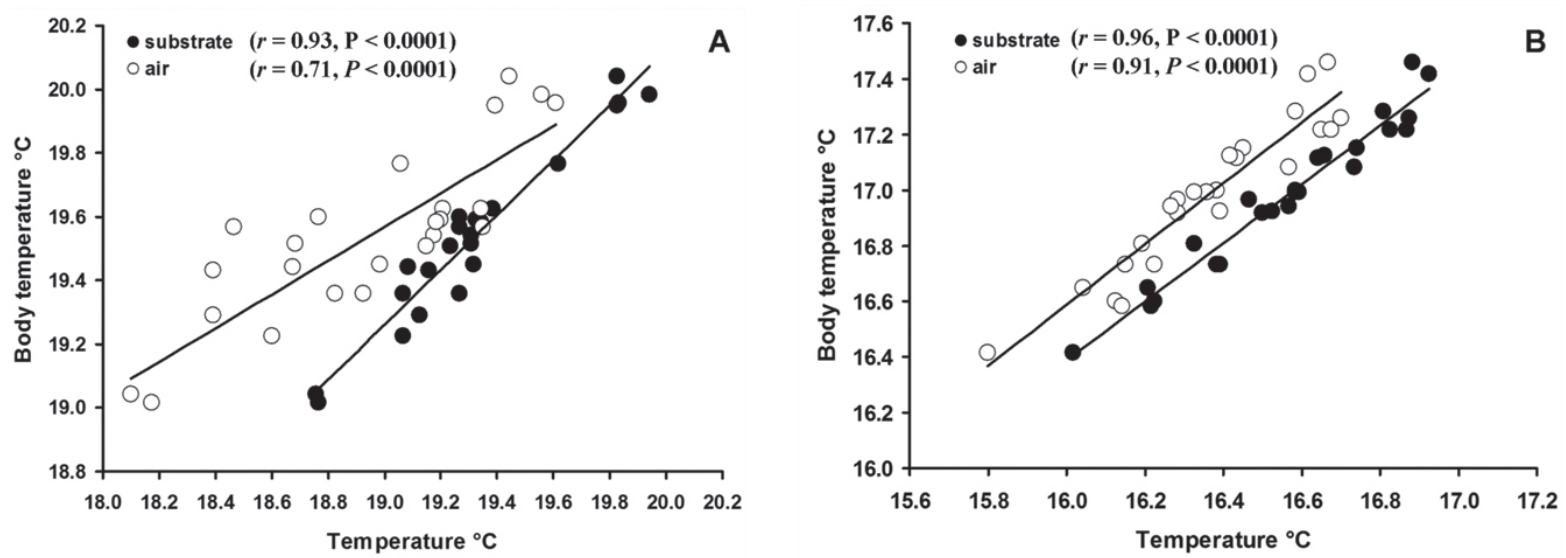

FIGURE 2: The relationship between body temperature and air and substrate temperature in laboratory conditions, during two periods: a) Activity hours (dusk), and b) inactivity hours (morning). For each case the correlation coefficient with its significance is given.

Figura 2: Relación entre la temperatura del cuerpo con la temperatura del aire y del sustrato en condiciones de laboratorio, durante dos periodos: a) horas de actividad (anochecer) y b) horas de inactividad (en la mañana). Para cada caso se entrega el coeficiente de correlación y su significancia.
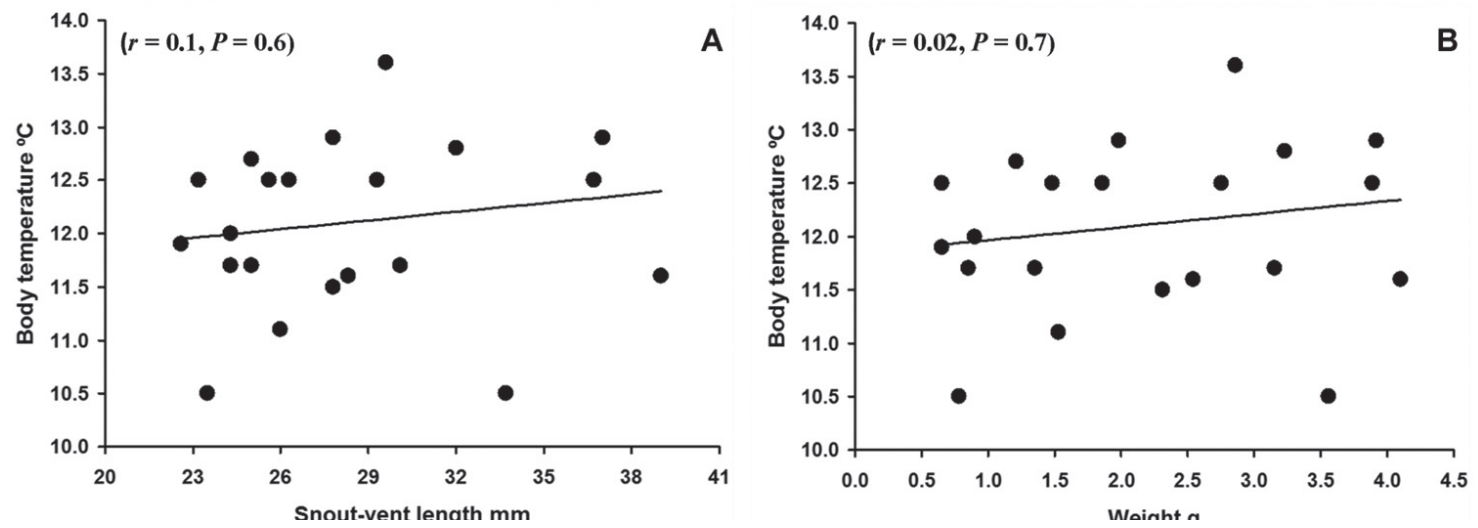

FIGURE 3: Relationship between body temperature and (a) snout-vent length, and (b) body mass. For each case the correlation coefficient with its significance is given.

Figura 3: Relación entre la temperatura del cuerpo y (a) largo hocico - cloaca, y (b) peso. Para cada caso se entrega el coeficiente de correlación y su significancia.

\section{ACKNOWLEDGEMENTS}

We thank Gustavo Valenzuela and Jonathan Guzmán for their field assistance and Dr. Lafayette Eaton for comments in previous version of manuscript. Frogs were collected with permission from the Servicio Agrícola y Ganadero de Chile (SAG) N 1519.

\section{BIBLIOGRAPHY}

Alford, R.A. \& Richards, S.J. 1999. Global amphibian declines: a problem in applied ecology. Annual Review of Ecology and Systematics 30:133-65.

Alford, R.A., Bradfield, K.S. \& Richards, S.J. 2007. Global warming and amphibian losses. Nature 447: E3-E4.

Angilletta, M.J., Niewiarowski, P.H. \& Navas, C.A. 2002. The evolution of thermal physiology in ectotherms. Journal of Thermal Biology 27:249-268. 
Castañeda, L.E., Lardies, M.A. \& Bozinovic, F. 2004. Adaptative latitudinal shifts in the termal physiology of a terrestrial isopod. Evolutionary Ecology Research 6:579-593.

Casterlin, M.E., \& Reynolds, W.W. 1978. Behavioral thermoregulation in Rana pipiens tadpoles. Journal of Thermal of Biology 3:143-145.

Correa, C., Sallaberry, M., González, B., Soto, E. \& Méndez, M.A. 2007. Notes on geographic distribution: Amphibia, Anura, Leiuperidae, Pleurodema thaul: Latitudinal and altitudinal distribution extension in Chile. Check List 3:267-270.

Cossins, A.R. \& Bowler, K. 1987. Temperature Biology of Animals. Chapman and Hall, London, United Kingdom. $339 \mathrm{pp}$.

Díaz-PÁez, H. \& Ortiz, J.C. 1995. Contribución a la Historia Natural de Pleurodema thaul Lesson. ¿Es el esfuerzo reproductivo determinado por la edad? Noticiero de Biología 3:131.

Feehan, J., Harley, M. \& van Minnen, J. 2009. Climate change in Europe. 1 Impact on terrestrial ecosystems and biodiversity. A review. Agronomy for Sustainable Development 29:409421.

Felton, A., Fischer, J., Lindenmayer, D.B., Montague-Drake, R., Lowe, A.R., Saunders, D., Felton, A.M., Steffen, W., Munro, N.T., Youngentob, K., Gillen, J., Gibbons, P., Bruzgul, J.E., Fazey, I., Bond, S.J., Elliott, C.P., Macdonald, B.C.T., Porfirio, L.L., Westgate, M. \& Worthy, M. 2009. Climate change, conservation and management: an assessment of the peer-reviewed scientific journal literature. Biodiversity and Conservation 18:22432253.

Gibbons, J.W., Scott, D.E., Ryan, T.J., Buhlmann, K.A. \& Tuberville, T.D. 2000. The global decline of reptiles, déjà vu amphibians. Bioscience 50:653-666.

Gilchrist, G.W. 1995. Specialist and generalist in changing environments: Fitness landscapes of thermal sensitivity. American Naturalist 146:252-270.

HueY, R.B. 1982. Temperature, physiology and the ecology of reptiles. In Biology of Reptilia (Eds. Gans, C. \& F.H. Pough), pp. 25-91. Academic Press, London, United Kingdom.

JoRgENSEN, C.B. 1992. Growth and reproduction: In: Environmental physiology of the amphibians (Eds. Feder, M.E. \& W.W. Burggren), pp. 439-466. University of Chicago Press, Chicago, Illinois.

Kearney, M., Shine, R. \& Porter, W.P. 2009. The potential for behavioral thermoregulation to buffer "cold-blooded" animals against climate warming. Proceedings of the National Academy of Sciences of the United States of America 106:3835-3840.

KeEn W.H. \& Schroeder, E.E. 1975. Temperature selection and tolerance in three species of Ambystoma larvae. Copeia 1975: 523-530.

Kusano, T. \& Inoue, M. 2008. Long.term trends towards earlier breeding of japanese amphibians. Journal of Herpetology 42: 608-614.

Labra, A. \& Vidal, M. 2003. Thermoregulation in reptiles: Un pasado veloz y un futuro lento. In: Fisiología Ecológica y Evolutiva. Conceptos y casos de estudios en animales (Ed. Bozinovic, F.), pp. 207-224. Ediciones Universidad
Católica de Chile, Santiago, Chile.

Labra, A., Vidal, M.A., Solis, R. \& Penna, M. 2008. Ecofosiología de anfibios y reptiles. In: Herpetología de Chile (Eds. Vidal M.A. \& A. Labra), pp. 483-516. Springer Verlag, Santiago, Chile.

Lambrinos, J.G. \& Kleier, C.C. 2003. Thermoregulation of juvenile Andean toads (Bufo spinulosus) at $4300 \mathrm{~m}$. Journal of Thermal Biology 28:15-19.

LAURANCE, W.F. 2008. Global warming and amphibian extinctions in eastern Australia. Austral Ecology 33:1-9.

Lillywhite, B.H., Licht, P. \& Chelgren, P. 1973. The role of behavioral thermoregulation in the growth energetics of the toad, Bufo boreas. Ecology 54:375-383.

Lobos, G., Vidal, M., Correa, C., Labra, A., Díaz-Páez, H., Charrier, A., Rabanal, F., Díaz, S. \& Tala, Ch. 2013. Anfibios de Chile, un desafío para la conservación. Fundación Facultad de Ciencias Veterinarias y Pecuarias de la Universidad de Chile y Red Chilena de Herpetología. Santiago. 104 pp.

Navas, C.A., Jared, C. \& Antoniazzi, M.M. 2002. Water economy in the casque-headed tree-frog Corythomantis greeningi (Hylidae): role of behaviour, skin, and skull skincoossification. Journal of Zoology, London 257:525-532.

Parmesan, C., Ryrholm, N., Stefanescu, C., Hill, J.K., Thomas, C.D., Descimon, H., Huntley, B., Kaila, L., Kullberg, J., Tammaru, T., Tennent, W.J., Thomas, J.A. \& Warren, M. 1999. Poleward shifts in geographical ranges of butterfly species associated with regional warming. Nature 399:579583.

Pearson, O.P. \& BRAdFord, D.F. 1976. Thermoregulation of lizards and toads at high altitudes in Peru. Copeia 1976:155-170.

Penna, M. \& Solis, R. 1992. Anillos de crecimiento óseo y actividad reproductiva en machos de Pleurodema thaul (Anura-Amphibia). Revista Chilena de Anatomía 10:51.

Pörtner, H.O. 2002. Climate variation and physiology basis to temperature dependent biogeography: systemic to molecular hierarchy of thermal tolerance in animals. Comparative Biochemistry and Physiology 132:739-761.

Quintanilla, V. 1982. Geografía de Chile. Primera Edición. Instituto Geográfico Militar, Santiago, Chile.

Sanabria, E.A., Quiroga, L.B. \& Acosta, J.C. 2003. Ecología térmica de Leptodactylus ocellatus (Linnaeus, 1758) (Anura: Leptodactylidae) en los bañados de Zonda, San Juan, Argentina. Cuadernos de Herpetología 17:121-123.

Sanabria, E.A., Quiroga, L.B. \& AcostA, J.C. 2005. Termorregulación de adultos de Bufo arenarum (Hensel, 1867) (Anura: Bufonidae) en diferentes microhábitats de los humedales de Zonda, San Juan, Argentina. Revista Española de Herpetología 19:127-132.

Sanabria, E.A., Quiroga, L.B. \& Acosta, J.C. 2006. Pleurodema nebulosa. Body temperature. Hereptological review 37:207.

Sanabria, E., Vaira, M., Quiroga, L., Akmentins, M. \& Pereyra, L. 2014. Variation of thermal parameters in two different color morphs of a diurnal poison toad, Melanophryniscus rubriventris (Anura: Bufonidae). Journal of Thermal Biology 41: 1-5.

Sinervo, B., Méndez-de-la-Cruz, F., Miles, D., Heulin, B., Bastiaans, E., Villagrán-Santa Cruz, M., LaraResendiz, R., Martínez-Méndez, N., CaLderón-Espinosa, 
M.L., Meza-Lázaro, R., Gadsden, H., Avila, L.J., Morando, M., De la Riva, I.J., Victoriano, P, Duarte, C.,Ibargüengoytía, N., Aguilar, C., Massot, M., Lepetz, V., Oksanen, T.A., Chapple, D., Bauer, A.M., Branch, W.R., Clobert, J. \& Sites JR, J.W. 2010. Erosion of lizard diversity by climate change and altered thermal niches. Science 328:894-899.

SoKal, R. \& RoHLF, F.J. 1995. Biometry: the principles and practice of Statistics in Biological Research. W. H. Freeman and Co, New York.
Statsoft Inc. 2000. Statistica for Windows. Tulsa,Oklahoma, U.S.A.

Vidal, M.A., \& Labra, A. 2008. Herpetología de Chile. Springer Verlag, Santiago, Chile.

Woolrich-Piña, G.A., Oliver-Lopez, L., Lemos-Espinal, J.A. \& Sмiтн, H.M. 2006. Eleutherodactylus nitidus nitidus Body temperature. Herpetological Review. 37:444.

Zug, G.R., Vitt, L.G. \& Caldwell, G.P. 2001. Herpetology. An Introductory Biology of Amphibians and Reptiles. Academy Press. New York, USA.

Recibido: 29.04.13

Aceptado: 19.05 .14 